\title{
Reform Exploration of the Financial Management Professional Curriculum System in Private Higher Learning Institutions Aiming at the Integration of "Course, Certificate, Training, and Competition"
}

\begin{abstract}
Chunmei Bai ${ }^{1, *}$
${ }^{1}$ Modern College of Northwest University, Xi'an, Shaanxi, China

*Corresponding author. Email: 747982450@qq.com

ABSTRACT

Technological progress and policy changes have put forward new requirements for the reform of the financial management professional curriculum system in private higher learning institutions. The failure to effectively implement the practical training link, the traditional thinking of course professors, and the low participation rate and pass rate of certificate examinations are the main problems existing in the financial management professional curriculum system in private higher learning institutions. To solve the above problems, it is necessary to start from the four aspects of "course, certificate, training, and competition" to achieve a proper integration, in order to obtain good teaching results.
\end{abstract}

Keywords: Private higher learning institutions, Curriculum system reform, Financial management.

\section{INTRODUCTION}

Curriculum system reform is a compulsory course for any professional construction, and it is a continuous and never-ending task. With technological progress and policy changes, the reform of the financial management professional curriculum system in private higher learning institutions is imperative.

\section{THE BASIS FOR THE REFORM OF THE FINANCIAL MANAGEMENT PROFESSIONAL CURRICULUM SYSTEM IN PRIVATE HIGHER LEARNING INSTITUTIONS}

The new "National Standards for Undergraduate Professional Teaching Quality in General Institutes of Higher Education" proposes the following two

*Fund: This paper is supported by phased research result of 2021 university-level education reform project of Northwest University - "Reform Exploration of the Financial Management Professional Curriculum System in Private Higher Learning Institutions Aiming at the Integration of "Course, Certificate, Training, and Competition"(No. : 21JG01). basic principles. The first is to highlight the student-centeredness, focus on stimulating students' interest and potential in learning, innovate forms, reform teaching methods, and strengthen practice so as to promote the transformation of undergraduate teaching from "teaching well" to "learning well"; the second is to highlight output orientation, actively meet the needs of economic and social development, scientifically and reasonably set the goal of talent training, improve talent training programs, optimize curriculum settings, update teaching content, effectively improve the social adaptability of talent training and the degree of condition guarantee, and increase the effectiveness and satisfaction of results. In accordance with the requirements of the new national standards, compressing classroom teaching, strengthening practical links, and focusing on the cultivation of students' practical ability, creative ability and independent learning ability are the direction of economic management professional curriculum reform. [1]

In addition, driven by technological progress and national policies, the use of new teaching methods and online and offline mixed teaching 
have reached unprecedented heights, which will be an essential part of the construction of university curriculum system for a long time to come.

The financial management major is a traditional superior major in colleges and universities as well as a popular major that has lasted for many years. After graduation, students are mainly employed in financial institutions or corporate finance departments. Affected by the particularity of the employment position, it is difficult to implement professional curriculum practice, practical training, and graduation field work. It is unlikely that a financial institution or corporate finance department would leave its substantive business to be viewed, participated in or even operated by interns.

Most of China's private higher learning institutions fall into the category of "second-batch universities" and the overall foundation of students is weaker than that of state-run undergraduates. The schools have the typical traditional teaching model and the teaching content is mainly based on textbooks. Teachers talk, students listen, and exams will be taken step by step. The final result caused is that the professional characteristics are not distinctive and the employment competitiveness is not strong.

How can students learn something and gain a tiny place in the fiercely competitive job market during university? Consolidating classroom teaching through professional practice, focusing on the cultivation of hands-on ability, and obtaining basic practitioner qualifications have become important tasks among the training objectives.

\section{PROBLEMS TO BE SOLVED IN THE REFORM OF THE FINANCIAL MANAGEMENT PROFESSIONAL CURRICULUM SYSTEM IN PRIVATE HIGHER LEARNING INSTITUTIONS}

First, the practice and training links have not been effectively implemented. Students majoring in financial management in private higher learning institutions should highlight their hands-on ability. They should master basic data collection, basic business operations, and data processing. At present, in the actual teaching process, teachers take up most of the class time explaining the basic concepts and theories. The curriculum practice of each professional course and all kinds of professional practice basically become formalistic. Difficulty in establishing practice bases, difficulty in contacting internship units, incomplete experimental facilities, and teachers and students not paying attention to practice in their thinking are all important reasons.

Second, the thinking of the course teaching is relatively traditional, and the concept of "taking student learning as the principal thing" has not been reflected. Teachers are still the centers of the classroom. The most common teaching process is that teachers lecture, and students attend lectures, do homework after class and take a final exam. Teaching methods that emphasize student autonomy such as flipped classroom, students' hands-on operation, group discussion, online data self-study, summary and induction, etc. are used very rarely. The use of modern teaching technology to design and control the teaching links, the enrichment of teaching content, and the expansion of teacher-student interactive communication channels have not been implemented well. [2]

Third, the certificate examination has a low participation rate and a low pass rate.

Obtaining as many professional qualification certificates as possible during the school period is of great help to increase the employment rate of students. At the same time, obtaining certificates itself can greatly promote learning. The financial management major has a complete certification system. The main problem at the moment is that students are fighting on their own and cannot figure it out in the mind. Students are confused about what certificate they should obtain at what time, the level of difficulty of the examination, how to review and many other issues. The examination participation rate is low, and the pass rate is low. The role of the teacher as a guide and tutor is less played.

Fourth, "course, certificate, training, and competition" are separated from each other and fail to link up effectively. The main task of the course teacher is to lecture, the certificate examination is decided by the students themselves, the practical training becomes a mere formality, and competitions cannot be effectively organized... These are the current status of most private higher learning institutions. But from the perspective of training objectives, these four aspects are interlocking and interdependent, and they are also very needed by students. 


\section{THE DIRECTION AND MEASURES IN THE REFORM OF THE FINANCIAL MANAGEMENT PROFESSIONAL CURRICULUM SYSTEM IN PRIVATE HIGHER LEARNING INSTITUTIONS}

Based on the analysis of the above problems, the reform of the financial management professional curriculum system should focus on the four aspects of "course", "certification", "training" and "competition".

\section{1 "Course"}

Classroom teaching is the main front of professional education. The focus of "course" reform should be placed on the following aspects: teaching content, teaching model, teaching platform, etc.

In terms of teaching content, on the basis of traditional teaching content, when formulating training programs, courses should take into account the major professional qualifications, such as junior accountants, banking, security, and fund related courses. In the specific teaching process, teachers need to explain the key and difficult points of the certificate examination under the premise of complying with the syllabus. Course teachers need to be familiar with the basic content and difficulty level of various certificate examinations, and intersperse the exam content involved in this course into the teaching process. In addition, in accordance with relevant regulations, teachers should put the content of curriculum ideology into the classroom in a timely manner, and finally achieve the purpose of effective integration of professional basic knowledge, certificate examination content, and curriculum ideology.

In terms of teaching model, a student-centered teaching model should be established as soon as possible. After all, the class time is limited. Whether it is the content of the certificate examination or the implantation of the ideological elements of the curriculum, it is based on the premise of effective professional basic knowledge learning. After mixed teaching, it is not just the delivery of the lesson that makes a teacher excellent or not but also the design of the class. To effectively complete the teaching task, the teaching model in which the teacher lectures, the students listen and the students are tied to the teacher should be changed. [3] The main task of classroom teaching is to summarize, discuss and share, and answer questions. This requires teachers to carefully design and make full preparations before class. Relevant content, for example, what content needs to be previewed by students in advance, what materials should be sent to students in advance for reading, what topics should be given to students to practice after class, the content and topics of classroom interaction, the knowledge points that need to be summarized, the important and difficult points that need to be explained, etc., should be arranged in an orderly manner. In terms of teaching platform, online and offline mixed teaching is an indispensable supporting medium. The basic concepts and basic logical framework of the course can be explained using abundant MOOC resources. For important and difficult points, teachers can make a micro-course in advance and upload it to the platform. The certificate examination exercises related to this chapter and this section, including a large amount of reading materials, can also be uploaded to the platform. Students can make full use of their spare time to complete the learning of the above-mentioned online resources. In this way, during the offline class time, teachers and students can concentrate on communicating and reporting online learning results, and completing the summary and the answering of questions of knowledge points. Of course, in the process of mixed teaching, teachers must pay attention to the supervision and guidance of students' online learning, and establish appropriate assessment and incentive mechanisms to ensure that students participate in every link and learn something. [4] Teaching platforms such as "Rain Classroom", "Yunbanke", and "Tencent Classroom" can be made use of.

\section{2 "Certificate"}

It mainly starts from the following aspects:

As mentioned earlier, it is an effective method and means to put the content of the certificate examination into the course teaching process so that students can learn more systematically.

Sorting out and planning: for students, their understanding of the certificate is not systematic. It is best to let them have a more complete understanding of the certificate examination at the beginning of enrollment. Questions such as what certificates to obtain, when to take exams, and what the difficulty level it is should be informed to students so that they can plan ahead. The role of the teacher is not only to tutor students and explain 
knowledge during the course, but also to provide guidance and help students to plan. Certificates in English CET-4 and CET-6, computer operation, and Mandarin are required for the foundation, and the grades of the students taking exams can be free of restrictions. Junior accountants, management accountants, banking, security, fund, etc. are greatly affected by the progress of professional courses. When making training programs, departments need to systematically master the requirements of various certificates, and it is important to plan the test time, what courses are offered in which semester, what certificates should be obtained, and how to link up well with the course. After the corresponding planning is completed, it will be relatively fixed and will be implemented on a rolling basis for each grade.

Centralized mobilization, organization and guidance: in order to help students improve the pass rate of the certificate examination, department-level tutoring courses (optional courses) can be opened in each semester for targeted reinforcement and training.

\section{3 "Training"}

"Training" means practical training or practice. The practical training closely related to professional education mainly includes the following links: practical hours of each course, final practice week, social practice in winter and summer vacation, and graduation internship. ERP sand table simulation, corporate accounting software learning, manual accounting, and establishment of practice bases are the most commonly used training methods. On the one hand, these traditional training methods have a large gap with actual operation, and on the other hand, they fail to systematically carry out the practice links of different courses. [5]

As for how to implement the practical training at different periods of time, a combination of measures is needed. Expansion of practice and practice bases, and improvement of experimental facilities on campus are all means that cannot be given up. With the development of network technology, virtual simulation experiments that have appeared in recent years provide a very good way to solve the above problems. For example, the virtual simulation system based on the "National University Economic Decision-Making Virtual Experiment Competition" hosted by the Chinese Association of Quantitative Economics provides a relatively realistic system for the practical training of many courses such as macro and micro economics, finance, monetary banking, and commercial bank management and so on. Through the exercise of the simulation system, students experience firsthand how companies purchase raw materials at reasonable prices, put them into production in proportion, and determine reasonable prices for sales. If there is a mistake in one link, it may lead to insufficient supply of raw materials, overstock or loss or even bankruptcy. The way for banks to survive is to attract deposits, issue loans, and earn interest margins. They need to follow the basic principles of safety, liquidity, and profitability. Only by letting students practice can they understand why banks should maintain sufficient liquidity, how to determine a reasonable interest rate, and what factors affect higher profitability, and so on. Through the practice of virtual simulation, students can understand the principles and theories taught by the teacher in class.

On the one hand, an excellent virtual simulation system can allow students to practice in turn according to the content learned in different chapters, and it can also help students to operate the system, consider problems from an overall perspective, and establish connections between knowledge points. At present, there are relatively complete virtual simulation systems for modules such as investment, enterprise operation, and accounting processing. Schools can learn from and use them according to their own conditions to make up for the lack of effective implementation of the practical training links.

\section{4 "Competition"}

"Competition" specifically refers to competitions closely related to professional courses. [6] From the school level, encouraging students to participate in competitions and compete with other college students on the same stage is not only a process of student learning and practice, but also a good publicity chance for the school. Government sectors, societies at all levels and enterprises will organize various types of competitions. Among these competitions, the competitions organized by government sectors are formal and the honor certificates contain high gold content, followed by the competitions organized by societies. The competitions held by enterprises have obvious profitability or product sales tendencies, and the good and bad are intermingled and they need to be carefully distinguished. How can the competition be used as a "training ground" for 
professional courses? This requires efforts from the following aspects.

\subsubsection{Sorting out}

There should be one competition for one course, even several competitions for one course. Course teachers can collect information extensively, choose a competition that suits the abilities and levels of the students of the school, and then make it a fixed competition. Students may also participate in the competition in conjunction with other professional courses.

\subsubsection{Organization}

Organisation is crucial to a good result in any competition. To establish a competition responsibility system, the different teaching and research offices of the departments must form a joint force. Each competition has a special person in charge, and other teachers work together in promoting, registering, guiding and following up to ensure that each task is carried out in a practical manner. Only in this way can it be ensured that more students participate in the competition and achieve ideal results.

\subsubsection{Doing a Good Job in the Connection with the Course}

With the development of virtual simulation technology, there are more and more competitions for the practical link of a certain course. Competitions such as economic decision-making, brain bank operations, public management decision-making, organizational management capabilities, accounting practice operations, and stock investment have emerged one after another. Course teachers need to link these competitions well with the teaching content, on the one hand to ensure the course practice links, and on the other hand to provide a basis for competitions.

\section{CONCLUSION}

In order to adapt to the new environmental changes and enhance the competitiveness of students majoring in financial management in private colleges, the integration of "course, certificate, training and competition" is the only way to go. Schools should make full use of the online and offline blended teaching mode to integrate "course, certificate, training and competition" in order to achieve good teaching effects.

\section{AUTHORS' CONTRIBUTIONS}

This paper is independently completed by Chunmei Bai.

\section{REFERENCES}

[1] "National Standards for Undergraduate Professional Teaching Quality in General Institutes of Higher Education", Website of the Ministry of Education of the People's Republic of China: http://so.moe.gov.cn/http://so.moe.gov.cn/

[2] Tang Qiao, LAI Hongbo, LUO Fang. Teaching Reform and Practice of the Course" International Trade Practice"-Discussion on the Practice of Integration of Lecturing, Simulation Training, Competition and Certification. Journal of University of Shanghai for Science and Technology. Vol. 42 No. 3Sept. 2020: 292-296

[3] Jihong Zhu. The Talent Cultivation Model of Accounting Major "Class Certificate Training Competition Integration" in the Era of "Great Wisdom Moving Cloud Block-chain” Realization Path. Education and Teaching Forum. Sept. 2021No.36: 177-180.

[4] Yaxiang Zhao. "Integration of Innovation and Professional Education" in Universities of Liberal Arts: Framework Construction and Teaching Practice. Journal of Southwest University of Political Science \& Law Aug. 2019Vol. 21 No. 4:118-122.

[5] ZHANG Yi-xin, CHEN Chen, YIN Ming-hua Zhang.A. Analysis of Dialectical relationship among "Competition, Teaching, Learning and Training" - Taking Life Science College of Shangrao Normal University as an Example. Teaching of Forestry Region. No . 05 2020General No. 278:28-30.

[6] Lin Jiamin. Practice and Exploration of Curriculum Reform Based on "Promoting Learning by Competition and Promoting Training by Competition" - Through Taking the Sign Language Course of Air Services as an Example. Heilongjiang Science. Vol. 12Apr. 2021:32-36. 